\title{
The effects of linseed and rape seed cultivars and fish oil on the fatty acid profile of cow milk fat
}

\author{
M. Zymon ${ }^{1}$, J. Strzetelski ${ }^{1,4}$, J. Kowalczyk ${ }^{2}$ and S. Osięgłowski ${ }^{3}$ \\ ${ }^{I}$ National Research Institute of Animal Production \\ 32-083 Balice, Poland \\ ${ }^{2}$ The Kielanowski Institute of Animal Physiology and Nutrition, Polish Academy of Sciences \\ 05-110 Jablonna, Poland \\ ${ }^{3}$ National Research Institute of Animal Production, Experimental Farm \\ 64-122 Pawlowice, Poland
}

\begin{abstract}
Twenty-eight Black-and-White cows were allotted to 7 groups of 4 each and fed for 8 weeks basal ration containing maize, lucerne and beet pulp silage, wet brewer's grains and meadow hay and different concentrate mixtures without additives (control group) or supplemented with: 10\% linseed (Omega, Linola or Opal cv.), rape seed (Spencer or Contact cv.), or 4\% fish oil as fat sources in the respective experimental groups. Each ingredient of basal diet and concentrates were given separately. Cows fed diets enriched with vegetable oils produced more milk containing a somewhat lower level of fat, protein and lactose than control cows. Omega or Opal cv. linseeds resulted in an increase in n-3 PUFA, but Linola cv. linseed raised the n-6 PUFA proportion in milk fat. Feeding diets supplemented with fat resulted in a decrease of SFA and increase of the CLA proportion in milk fat, particularly when feeding fish oil.
\end{abstract}

KEY WORDS: linseed, rape seed, fish oil, cow milk, fatty acids

\section{INTRODUCTION}

Numerous recent studies have demonstrated that the composition of fatty acids in cow milk can be favourably modified from the point of view of human health through appropriate nutrition of cows.

The aim of the present study was to establish the effect of feeding dairy cows oilseeds containing different proportions of polyunsaturated fatty acids,

$\overline{{ }^{4} \text { Corresponding author: e-mail: jstrzet@izoo.krakow.pl }}$ 
particularly linoleic or linolenic acids, or fish oil rich in eicosapentanoic (EPA) and docosahexaenoic (DHA) acids, to obtain milk with an increased n-3 PUFA content in milk fat.

\section{MATERIAL AND METHODS}

Twenty-eight Polish Holstein-Friesian dairy cows in week 13 to 20 of lactation and lactation no.1-4, with a daily milk yield of 24 to $45 \mathrm{~L}$ were allotted by an analog method to 7 groups of 4 cows each and fed individually for 8 weeks according to IZ-INRA (2001) standards depended on milk yield. The basal ration was composed of, $\mathrm{kg} \mathrm{DM}$ /day: 6.3-8.0 maize silage (predicted to voluntary intake), 6.1 lucerne silage, 1.2 beet pulp silage, 1.2 wet brewer's grains, 1.26 meadow hay and was supplemented with soyabean oilmeal ( $0.0-0.8 \mathrm{~kg} /$ day $)$ as a feed equalizing protein and energy for milk production. Different concentrates, \%: barley (40-45), wheat (13-30.5), wheat bran (6-13), soyabean oilmeal (12.5-15.5), mineral mixture (3.5) without fat additives for the control group (C) or concentrate supplemented with $10 \%$ of linseed from the varieties: Opal (Group LOP), Omega (Group LOM), Linola (group LL) or rape seed: Spencer (Group RS) or Contact (Group RC), or with a 4\% supplement of fish oil (Group FO) were offered in separate feed bin fixed the through. Maize silage, beet pulp silage and brewer's grains were offered one after the other in the morning and lucerne silage and meadow hay in the afternoon. Concentrates (4.7-10.3 kg/day) were given three times a day.

Milk production was measured each day, samples of milk for analyses of nutrient content (MilkoScan FT120) and fatty acids (GC Varian 3400, column Rtx, $105 \mathrm{~m}, 0.32 \mathrm{~mm}, 0.2 \mu \mathrm{m}$ ) were taken and analysed once of each week. For calculation was accepted the means from all eight analyses. Nutrients in feeds and refusals were analysed according to AOAC (1990).

Statistical analysis of results was carried out using one-way analysis of variance (ANNOVA, test $\mathrm{F}$, multiple range test REGWQ) using a computer program and two-way analysis of variance (SAS Enterprise Guide 2.0., 2002).

\section{RESULTS AND DISCUSSION}

All concentrates supplemented with fat contained on average: $87.8 \pm 0.4 \% \mathrm{DM}$, $177.3 \pm 4.3 \mathrm{~g}$ crude protein $(\mathrm{CP})$ and $1.11 \pm 0.01 \mathrm{UFL}$ (unit feed for milk production, $1 \mathrm{UFL}=1.7 \mathrm{Mcal}$ net energy for lactation) and concentrate with vegetable oil seeds $111.2 \pm 1.2 \mathrm{~g}$ PDI and for group FO $123 \mathrm{~g}$ PDI in $1 \mathrm{~kg}$ DM. Concentrate for group C contained: $87.2 \% \mathrm{DM}$ and $173 \mathrm{~g} \mathrm{CP}, 118 \mathrm{~g}$ PDI and $1.10 \mathrm{UFL}$ in $1 \mathrm{~kg}$ $\mathrm{DM}$. The fat content in the concentrate for the control group was $16 \mathrm{~g}$, but in the 
concentrate with added fat, $56 \pm 0.18 \mathrm{~g} / \mathrm{kg} \mathrm{DM}$, of which $72 \%$ originated from the respective oils. Intake of DM/day was mean 3.8\% of BW, from 23.6 (group LOM) to $25.3 \mathrm{~kg}(\mathrm{P}>0.05)$. Oil supplementation did not result in a decrease in daily dry matter intake in the present experiment as the level of fat in the DM was relatively low (Ward et al., 2002). Nonetheless, higher levels of fat in the diet can decrease feed intake as reported by Kowalczyk et al. (1977).

Milk production in the experimental period lasting 56 days was, kg: 1734 in the control group, 1734 (LOM group), 1804 (LL), 1843 (LOP), 1851 (RS), 1958 $(\mathrm{RC})$ and 1733 in FO group $(\mathrm{P}>0.05)$. Cows fed the diets with linseed or rape seed produced from 2.4 to $12.9 \%$ more milk than the animals in the control and fish oil groups.

Table 1 . Fatty acid proportion in vegetable oils and fish oil, $\%$ total fatty acids

\begin{tabular}{|c|c|c|c|c|c|c|}
\hline \multirow{2}{*}{ Fatty acid } & \multicolumn{3}{|c|}{ Linseed } & \multicolumn{2}{|c|}{ Rape seed } & \multirow{2}{*}{ Fish oil } \\
\hline & Omega & Linola & Opal & Spencer & Contact & \\
\hline$\overline{\mathrm{C} 18: 0}$ & 3.83 & 3.18 & 3.86 & 1.72 & 1.57 & 2.33 \\
\hline C18:1 & 18.20 & 13.00 & 21.02 & 56.87 & 67.78 & 25.23 \\
\hline C18:2 n-6 & 26.76 & 72.90 & 18.09 & 30.14 & 13.61 & 5.18 \\
\hline $\mathrm{C} 18: 3 \mathrm{n}-3$ & 41.87 & 2.84 & 51.18 & 3.71 & 9.63 & 3.41 \\
\hline C20:5 n-3 EPA & 0.00 & 0.04 & 0.07 & 0.00 & 0.03 & 7.87 \\
\hline C22:6 n-3 DHA & 0.00 & 0.06 & 0.01 & 0.00 & 0.00 & 12.91 \\
\hline SFA & 12.99 & 11.04 & 9.52 & 7.49 & 6.93 & 32.39 \\
\hline$n-6 / n-3$ & 0.64 & 24.48 & 0.36 & 8.12 & 1.41 & 0.21 \\
\hline
\end{tabular}

In comparison with the control group, the milk of cows in the experimental groups fed vegetable and fish oils contained slightly less fat (4.03-4.14 vs $4.16 \%$; $\mathrm{P}>0.05)$, lactose $(4.75-4.83$ vs $4.88 \% ; \mathrm{P}>0.05)$ and protein $(3.20-3.38$ vs $3.46 \%$; $\mathrm{P}>0.05$ ). The dry matter of milk did not differ among the groups (from 11.66 to $12.35 \%)$.

The sources of the fat supplemented in this experiment differed in their proportion of C18:2 n- 6 and C18:3 n-3 acids and content of oleic acid. Fish oil contained the highest level of EPA $(0.9 \%)$ and DHA (13\%), but the lowest level of C18:2 n-6 (5\%) and C18:3 n-3 (3\%) acids (Table 1).

Oilseeds or fish oil fed with the diet significantly affected the composition of fatty acids in milk fat (Table 2).

The milk of cows fed concentrate with vegetable oils with a higher proportion of UFA C18 (about $85 \%$ ) than control concentrate $(78 \%)$ or fish oil (48\%) contained less SFA, similarly as reported Palmquist et al. (1993) and Ward et al. (2002). A significantly lower C1 8:0 content in milk of cows from the FO group could probably have been caused by the lower level of PUFA-C18 in the diet. Moreover, fish oil has a restraining effect on the activity of rumen bacteria converting vaccenic acid (C18:1trans11) into stearic acid (Shingfield et al., 2003). The significant increase 
in the proportion of linoleic acid in the milk of cows offered concentrate mixture with Linola var. linseed, which contains a high proportion of C18:2 n-6 (50\%), and the increase in the proportion of linolenic acid in the milk of cows offered concentrate mixtures with Omega and Opal var. linseed, having high proportions of C18:3 n-3 (35 and 34\%, respectively) suggests that part of these acids avoided biohydrogenation and was incorporated directly into the milk fat in the mammary gland.

Table 2. Fatty acid proportions in milk fat, $g / 100 \mathrm{~g}$ of total fatty acids $(\mathrm{n}=4)$

\begin{tabular}{|c|c|c|c|c|c|c|c|c|c|}
\hline \multirow{2}{*}{ Fatty acid } & \multirow{2}{*}{ Control } & \multicolumn{3}{|c|}{ Linseed } & \multicolumn{2}{|c|}{ Rape seed } & \multirow{2}{*}{- Fish oil } & \multirow{2}{*}{ SEM } & \multirow{2}{*}{$P$} \\
\hline & & Omega & Linola & Opal & Spencer & Contact & & & \\
\hline C18:0 & $8.82^{b}$ & $11.56^{\mathrm{a}}$ & $11.18^{\mathrm{a}}$ & $8.85^{b}$ & $8.76^{b}$ & $8.71^{b}$ & $6.51^{\mathrm{c}}$ & 0.2 & $<0.01$ \\
\hline C18:1 & $19.86^{\mathrm{b}}$ & $23.17^{\mathrm{ab}}$ & $25.82^{\mathrm{a}}$ & $23.86^{\mathrm{a}}$ & $24.69^{\mathrm{a}}$ & $24.39^{\mathrm{a}}$ & $20.13^{b}$ & 0.34 & $<0.01$ \\
\hline C18:2 & $4.10^{\mathrm{b}}$ & $4.16^{b}$ & $5.57^{\mathrm{a}}$ & $3.91^{\mathrm{b}}$ & $4.04^{b}$ & $3.87^{\mathrm{b}}$ & $3.75^{\mathrm{b}}$ & 0.07 & $<0.01$ \\
\hline C18:3 & $0.29^{\mathrm{cd}}$ & $0.63^{\mathrm{a}}$ & $0.32^{\mathrm{c}}$ & $0.42^{b}$ & $0.22^{\mathrm{d}}$ & $0.23^{\mathrm{cd}}$ & $0.22^{\mathrm{d}}$ & 0.01 & $<0.01$ \\
\hline CLA & $0.99^{\mathrm{c}}$ & $1.51^{\mathrm{b}}$ & $1.65^{\mathrm{b}}$ & $1.38^{\mathrm{bc}}$ & $1.58^{\mathrm{b}}$ & $1.68^{\mathrm{b}}$ & $2.41^{\mathrm{a}}$ & 0.05 & $<0.01$ \\
\hline CLA $c 9-t 11$ & $0.72^{\mathrm{c}}$ & $1.15^{\mathrm{b}}$ & $1.26^{\mathrm{b}}$ & $1.01^{\mathrm{bc}}$ & $1.18^{\mathrm{b}}$ & $1.26^{\mathrm{b}}$ & $1.83^{\mathrm{a}}$ & 0.04 & $<0.01$ \\
\hline CLA $t 10-c 12$ & $0.01^{\mathrm{b}}$ & $0.01^{\mathrm{b}}$ & $0.01^{\mathrm{ab}}$ & $0.01^{\mathrm{ab}}$ & $0.02^{\mathrm{a}}$ & $0.02^{\mathrm{a}}$ & $0.02^{\mathrm{a}}$ & 0.001 & $<0.01$ \\
\hline CLA $c 9-c 11$ & $0.06^{\mathrm{c}}$ & $0.07^{\mathrm{c}}$ & $0.12^{\mathrm{ab}}$ & $0.09^{\mathrm{bc}}$ & $0.11^{\mathrm{b}}$ & $0.11^{\mathrm{b}}$ & $0.14^{\mathrm{a}}$ & 0.003 & $<0.01$ \\
\hline CLA $t 9-t 11$ & $0.19^{c}$ & $0.28^{b}$ & $0.25^{\mathrm{bc}}$ & $0.26^{\mathrm{bc}}$ & $0.28^{\mathrm{b}}$ & $0.29^{\mathrm{b}}$ & $0.42^{\mathrm{a}}$ & 0.008 & $<0.01$ \\
\hline EPA C20:5 & $0.04^{\mathrm{bc}}$ & $0.06^{\mathrm{a}}$ & $0.03^{\mathrm{cd}}$ & $0.05^{\mathrm{ab}}$ & $0.02^{\mathrm{d}}$ & $0.03^{\mathrm{cd}}$ & $0.04^{\mathrm{bc}}$ & 0.001 & $<0.01$ \\
\hline DHA C22:6 & $0.00^{\mathrm{b}}$ & $0.01^{\mathrm{b}}$ & $0.00^{\mathrm{b}}$ & $0.01^{\mathrm{b}}$ & $0.00^{\mathrm{b}}$ & $0.00^{\mathrm{b}}$ & $0.03^{\mathrm{a}}$ & 0.002 & $<0.01$ \\
\hline SFA & $72.96^{\mathrm{a}}$ & $69.07^{\mathrm{abc}}$ & $65.18^{c}$ & $68.66^{\mathrm{bc}}$ & $67.64^{\mathrm{bc}}$ & $67.88^{\mathrm{bc}}$ & $71.32^{\mathrm{ab}}$ & 0.39 & $<0.01$ \\
\hline MUFA & $21.37^{\mathrm{b}}$ & $24.27^{\mathrm{ab}}$ & $27.03^{\mathrm{a}}$ & $25.32^{\mathrm{a}}$ & $26.31^{\mathrm{a}}$ & $26.09^{\mathrm{a}}$ & $22.07^{b}$ & 0.35 & $<0.01$ \\
\hline PUFA n-6 & $4.36^{\mathrm{bc}}$ & $4.57^{\mathrm{b}}$ & $5.80^{\mathrm{a}}$ & $4.17^{\mathrm{bc}}$ & $4.22^{\mathrm{bc}}$ & $4.08^{\mathrm{bc}}$ & $3.91^{\mathrm{c}}$ & 0.07 & $<0.01$ \\
\hline PUFA n-3 & $0.33^{\mathrm{cd}}$ & $0.69^{\mathrm{a}}$ & $0.35^{\mathrm{c}}$ & $0.48^{\mathrm{b}}$ & $0.25^{\mathrm{d}}$ & $0.26^{\mathrm{cd}}$ & $0.29^{\mathrm{cd}}$ & 0.01 & $<0.01$ \\
\hline$n-6 / n-3$ & $12.97^{\mathrm{c}}$ & $6.80^{\mathrm{e}}$ & $17.02^{\mathrm{a}}$ & $9.69^{\mathrm{d}}$ & $17.37^{\mathrm{a}}$ & $15.94^{\mathrm{ab}}$ & $14.38^{\mathrm{bc}}$ & 0.36 & $<0.01$ \\
\hline
\end{tabular}

It is worth noting that the highest level of CLA was found in the milk of cows fed fish oil containing a much lower level of these acids compared with the other oils. A similar effect of fish oil was reported by AbuGazaleh et al. (2002). An explanation for that could be that fish oil is more effective than vegetable oils in elevating the cis9-trans11 level CLA in cow milk (Offer et al., 1999; Chouinard et al., 2001). The reason for the low transfer of EPA and DHA from fish oil into the milk could be that these acids are extensively biohydrogenated in the rumen or preferentially deposited in the body tissues rather than in milk (Wachira et al., 2000). Despite vegetable oils do not containing EPA or DHA, both were found in the milk when diets with Omega or Opal var. linseed were fed. According to Williams (2000) these acids can be synthesized in mammalian body tissues from linolenic acid. Diets containing Omega and Opal var. linseed resulted in an increase in the total amount of n-3 PUFA and decrease in the $n-6 / n-3$ ratio in milk, which is important from the point of view of human nutrition. 


\section{CONCLUSIONS}

Feeding cows diets supplemented with linseed var. Omega or Opal, rape seed var. Contact or Spencer or fish oil had diverse but beneficial effects on the proportions of those fatty acids in milk fat that are considered important for human health.

Feeding linseed var. Omega or Opal having a high C18:3 n-3/C18:2 n-6 ratio increased the n-3 PUFA level in milk, whereas linseed Linola var. with the highest content of C18:2 n-6 increased the level n-6 PUFA in milk. Feeding cows diets with linseed var. Omega or Opal resulted in a increase the EPA level and a decrease in the n-6/n-3 ratio in milk fat. Feeding of fish oil rich in EPA and DHA resulted in only a slight increase in the level of DHA but much more increase in CLA content in milk fat but did not decrease the $n-6 / n-3$ ratio.

\section{REFFERENCES}

Abu-Ghazaleh A.A., Schingoethe D.J., Hippen A.R., Kalscheur K.F., Whitlock L.A., 2002. Fatty acid profiles of milk and rumen digesta from cows fed fish oil, extruded soybeans or their blend. J. Dairy Sci. 85, 2266-2276

AOAC, 1990. Association of Official Analytical Chemists, Official Methods of Analysis. 15 Edition. Arlington, VA

Chouinard P.Y., Corneau L., Butler W.R., Chiliard Y., Drackley J.K., Bauman D.E., 2001. Effect of dietary lipid source on conjugated linoleic acid and concentrations in milk fat. J. Dairy Sci. 84, 680-690

IZ-INRA, 2001. Standards for Cattle, Sheep and Goats Nutrition (in Polish). Research Institute of Animal Production, Kraków (Poland)

Kowalczyk J., Ørskov E.R., Robinson J.J., Stewart C.S., 1977. Effect of fat supplementation on voluntary food intake and rumen metabolism in sheep. Brit. J. Nutr. 37, 251-257

Offer N.W., Mardsen N., Dixon J., Speake B.K., Thacker F.E., 1999. Effect of diery fat supplements on levels of n-3 polyunsaturated fatty acids, trans acids and coniugated linoleic acid in bovine milk. Anim. Sci. 69, 613-625

Palmquist D.L., Beaulieu A.D., Barbano D.M., 1993. Feeds and animal factors influencing milk fat composition. J. Dairy Sci. 76, 1753-1771

SAS Enterprise Guide, 2002. Version 2.0, SAS Institute Inc., Cary, NC

Shingfield K.J., Ahvenjarvi S., Toivonen V., Arola A., Nurmela K.V.V., Huhtanen P., Griinari J.M., 2003. Effect of dietary fish oil on biohydrogenation of fatty acids and milk fatty acid content in cows. Anim. Sci. 77, 165-179

Wachira A.M., Sinclair L.A., Wilkinson R.G., Hallett K., Enser M., Wood J.D., 2000. Rumen biohydrogenation of $n-3$ polyunsaturated fatty acids and their effects on microbial efficiency and nutrient digestibility in sheep. J. Agr. Sci. 135, 419-428

Ward A.T., Wittenberg K.M., Przybylski R., 2002. Bovine milk fatty acid profiles produced by feeding diets containing solin, flax and canola. J. Dairy Sci. 85, 1191-1196

Williams C.M., 2000. Dietary fatty acids and human health. Ann. Zootech. 49, 161-292 